Editorial

\title{
Protection of minimum environmental flow of river Ganga
}

\section{Editorial}

River Ganga is the most sacred and deeply revered by the people of this country and the Ganga river basin is the largest river basin in India in terms of catchment area, constituting twenty six per cent of the country's land mass and supporting about half a billion population. River Ganga is unique as having special properties, features and importance, holding reasons that are hydrological, geomorphological, historical, socio-cultural and economical with significant temporal and spatial flow variation. River Ganga has been given status of a National river and the ever increasing demand for water in the basin for irrigation, domestic, industrial and other purposes coupled with pollution ingress from different sources including domestic waste, industrial waste, into river system is affecting the health of the said river for long.

Cental Pollution Control Board (CPCB), New Delhi has inventoried and monitored 138 drains in Ganga River Catchment. $76 \%$ of the pollution load was contributed by Uttar Pradesh. Maximum flow was also measured in Uttar Pradesh. In Uttar Pradesh, Chhoyia, Permiya, Sisamau nala are the major polluters which contributes maximum pollution load. In West Bengal maximum numbers (54) of point sources were identified. This indicates that if the pollution load in the major drains of Uttar Pradesh, Bihar and West Bengal is addressed, water quality would show substantial improvement. Haridwar is also known for two industrial estates namely Bharat Heavy Electrical Limited (BHEL) and SIDCUL, which have more than 500 companies. Sewage and municipal waste of Rishikesh and Haridwar as well as effluents of industrial units of BHEL and SIDCUL. About 15 large and small sewage drains discharge about 42 mid municipal sewage into the river. Community bathing discharges milk pots bunches of flowers and leaves etc. into the river. Approximately 1 billion liters of raw, untreated sewage are dumped in the river on a daily basis. The amount has more than doubled in the last 20 years and experts predict another $100 \%$ increase in the following 20 years. ${ }^{2}$

Government of India vide notification S.O. 3187(E), dated the $7^{\text {th }}$ October, 2016 under the Environment (Protection) Act, 1986 (29 of 1986) has constituted an authority, namely, the National Mission for Clean Ganga for Rejuvenation, Protection and Management of River Ganga basin for the following purposes, namely:

a) To determine the magnitude of ecological flow in the River Ganga and its tributaries required to be maintained at different
Volume 3 Issue 5 - 2018

\author{
Ashok K Rathoure \\ GM-Technical, Eco Chem Sales \& Services, India
}

Correspondence: Ashok K Rathoure C/o Sh. GK Rathoure, Mayashivraj Sadan, Gupta Colony, Hardoi-24I00I, UP, India, Tel +91 945050I471, Email asukumr@gmail.com

Received: October II, 2018 | Published: October 15, 2018

points in different areas at all times with the aim of ensuring water quality and environmentally sustainable rejuvenation, protection and management of River Ganga and its tributaries and notifying the same and take or direct all such measures necessary to maintain adequate ecological flows.

b) To specify the average flow of water at specified points through Hydrological Observation Stations of the River Ganga.

c) To devise a system for continuous monitoring of flow of water in the River Ganga and its tributaries.

Now, S.O. 5195 (E) dated Oct $9^{\text {th }}, 2018$; Government of India, New Delhi has notified minimum environmental flows to be maintained at locations downstream of structures or projects meant for diversion of river flows for purposes like irrigation, hydropower, domestic and industrial and other requirements:

i. Upper Ganga river basin stretch: starting from originating glaciers and through respective confluences finally meeting at Devaprayag up to Haridwar.

\begin{tabular}{|c|c|c|c|}
\hline S.No. & Season & Month & $\begin{array}{l}\% \text { Percentage of } \\
\text { monthly average flow }\end{array}$ \\
\hline & & & $\begin{array}{l}\text { Observed during each of } \\
\text { preceding 10-daily period }\end{array}$ \\
\hline I & Dry & November to March & 20 \\
\hline 2 & Lean & October, April \& May & 25 \\
\hline 3 & $\begin{array}{l}\text { High Flow } \\
\text { Season }\end{array}$ & June to September & 30 \\
\hline
\end{tabular}

Source: MoEFCC New Delhi

ii. Stretch of main stem of river Ganga from Haridwar, Uttrakhand to Unnao, Uttar Pradesh

\begin{tabular}{llll}
\hline \multirow{2}{*}{ S.No. } & \multirow{2}{*}{ Location of Barrage } & \multicolumn{2}{c}{ Minimum flow releases immediately downstream of Barrages (Cubic Meter per second) } \\
\cline { 3 - 4 } & Non-monsoon (October to May) & Monsoon (June to September) \\
\hline I & Bhimgoda (Haridwar) & 36 & 57 \\
2 & Bijnor & 24 & 48 \\
3 & Narora & 24 & 48 \\
4 & Kanpur & 24 & 48 \\
\hline
\end{tabular}

Source: MoEFCC New Delhi 


\section{iii. The above said ecological flows are subject to the following:}

a) The compliance of minimum environmental flow is applicable to all existing, under-construction and future projects.

b) The existing projects, which currently do not meet the norms of these environmental flows, shall comply and ensure that the desired environmental flow norms are compiled within a period of three years from the date of issue of this order.

c) The project which is at different stages of construction, where physical progress on ground has been initiated and made and reported to appropriate authority shall also make necessary provisions to maintain the stipulated environmental flow before and after commissioning of the project.

d) The mini and micro projects which do not alter the flow characteristics of the river or stream significantly are exempted from these environmental flows.

e) To ensure the release of desired quantities of water to maintain environmental flows, flow conditions in these river reaches shall be monitored at hourly intervals from time to time.

f) The Central Water Commission (CWC) shall be the designated authority and the custodian of the data and shall be responsible for supervision, monitoring, regulation of flows and reporting of necessary information to the appropriate authority as and when required and also authorized to take emergent decisions about the water storage norms in case of any emergency. The Central Water Commission shall submit flow monitoring-cumcompliance report on quarterly basis to National Mission for Clean Ganga.

g) The concerned project developers or authorities shall install automatic data acquisition and data transmission facilities or required necessary infrastructure at project sites at appropriate locations specified by the Central Water Commission within six months from the date of this order. The installation, calibration, maintenance of flow monitoring facility shall be the responsibility of the project developers or authorities and they shall submit the data to the Central Water Commission from time to time.

h) The Government of India through National Mission for Clean Ganga may direct release of additional water in the River Ganga to meet special demand as and when required.

iv. The concerned Central and State authorities: shall implement demand side management plans to reduce water withdrawal from River Ganga by adopting good and scientific practices such as efficient method of irrigation, reuse and recycle of water including monitoring and regulation of ground water withdrawals for various purposes.

In the same time, Clean Ganga, Swatch Bharat Mission by Govt. of India and Rally for Rivers by Sadguru are other initiatives which intend to make a smooth flow of Rivers and its protection. There is an urgent need to protect the natural flow of all the rivers on the planet earth to sustain the life as well.

\section{Acknowledgements}

None.

\section{Conflict of interest}

Author declares that he has no conflict of interest.

\section{References}

1. Ministry of Environment, Forest and Climate Change. New Delhi: Indira Paryavaran Bhavan, Jor Bag Road; 2018.

2. Save The Ganges River. Scientific India. 2014. 